\title{
RESPON PERTUMBUHAN DAN MORTALITAS PEDET SAPI BALI DARI INDUK YANG DIBERI PAKAN TAMBAHAN DAN OBAT CACING
}

\author{
Rahmad Hardiono ${ }^{1}$, Takdir Saili ${ }^{2}$, La Ode Nafiu ${ }^{2}$ \\ ${ }^{1)}$ Alumnus Fakultas Peternakan UHO \\ ${ }^{2)}$ Staf Pengajar Fakultas Peternakan UHO
}

\begin{abstract}
Abstrak
Kelahiran dan pertumbuhan pedet di bawah umur 3 bulan sangat rendah di lapangan karena pakan induk bunting dan menyusui kurang tercukupi dan adanya infestasi cacing pada induk sapi. Penelitian ini bertujuan untuk mengetahui respon pertumbuhan pedet, perkembangan dimensi tubuh dan mortalitas pedet terhadap pemberian pakan tambahan dan obat cacing pada induk sapi Bali. Penelitihan ini menggunakan Rancangan Acak Lengkap (RAL) dengan tiga perlakuan yaitu kelompok sapi bunting yang diberi pakan tambahan dan obat cacing (P2), kelompok sapi Bali bunting yang diberi pakan tambahan tanpa obat cacing (P1), kelompok sapi Bali bunting yang tidak diberi pakan tambahan dan obat cacing (P0). Parameter yang diukur adalah bobot lahir, berat badan, ukuran dimensi tubuh yang meliputi panjang badan, lingkar dada, tinggi pundak dan mortalitas pedet. Hasil penelitihan menunjukkan bahwa rataan tertinggi semua parameter yang diukur diperoleh pada perlakuan (P2), masing-masing bobot badan $(57,90 \mathrm{~kg})$, lingkar dada $(86,25 \mathrm{~cm})$, tinggi gumba $(73,35 \mathrm{~cm})$ dan panjang badan $(66,70 \mathrm{~cm})$. Angka kematian anak ternak $0 \%$ karena tidak ada anak ternak yang mati selama penelitian. Namun demikian, hasil analisis ragam menunjukkan bahwa perlakuan tidak berpengaruh nyata terhadap parameter yang dievaluasi. Berdasarkan hasil tersebut disimpulkan bahwa pemberian pakan tambahan dan obat cacing pada induk sapi Bali tidak berpengaruh nyata terhadap bobot lahir, bobot badan, panjang badan, lingkar dada, tinggi pundak dan mortalitas. Penggunaan pakan tambahan dan obat cacing (P2) memberikan performans pedet sapi Bali yang lebih baik.
\end{abstract}

Kata kunci : Pertumbuhan dan mortalitas, pedet sapi Bali, Induk sapi Bali, Pakan tambahan, obat cacing.

\begin{abstract}
Calving and the growth of 3 months old calf were very low due to insufficient diet of cow during pregnancy and lactation, and the infestation of worms. The objective of this research was to evaluate the effect of feed supplement and worm drugs inclusion into diet of bali cow on calf growth and body dimension, and calf mortality. The research was designed using randomized completed design with three treatments: additional of feed supplement and worm drugs (P2), additional of feed supplement without worm drugs (P1), and without additional of feed supplement and worm drugs (P0). Parameters measured were birth weight, live weight, body dimensions covering body length, girth and shoulder height of calf, and calf mortality. The results showed that treatment P2 had the highest respond to live weight $(57.90 \mathrm{~kg})$, girth $(86.25 \mathrm{~cm})$, shoulder height $(73.35 \mathrm{~cm})$ and body length $(66.70 \mathrm{~cm})$. Mortality was not found in all treatments. However, analysis of variance results showed that the treatments had no significant effect on all parameter measured. Finally, it was concluded that feed supplement and worm drugs inclusion into diet of bali cow had no significant effect on calf growth and mortality.
\end{abstract}

Keywords: Growth, mortality, Bali calf, Bali cow, feed supplement, worm drugs. 


\section{PENDAHULUAN}

Sapi Bali merupakan ternak asli Indonesia yang banyak dipelihara oleh petani di Sulawesi Tenggara Peningkatan produksi sapi Bali terus diupayakan, antara lain meningkatkan manajemen pemeliharaan sapi pedet dan dara oleh peternak. Salah satu kelebihan sapi Bali adalah tingkat fertilitas yang tinggi. Namun demikian tingginya fertilitas pada induk sapi Bali ternyata diikuti dengan tingginya tingkat kematian pedet. Wirdahayati dan Bamualim (2003) melaporkan bahwa jumlah kematian dini pada pedet sapi Bali mencapai $30 \%$. Tingginya angka kematian pedet sebelum disapih merupakan faktor utama penyebab rendahnya produktivitas sapi Bali. Ada beberapa kendala yang dialami oleh peternak dalam beternak sapi Bali, diantaranya permasalahan pakan dan nutrisi, pencegahan dan pemberantasan penyakit serta penanggulangan limbah (Deptan, 2001).

Sistem pemeliharaan sapi Bali di Sulawesi Tenggara umumnya masih dilakukan secara ekstensif dan semi intensif. Sistem pemeliharaan sapi Bali yang masi tergolong tradisional seperti inilah yang rentan terhadap infeksi dari berbagai macam penyakit. Keadaan ini mengakibatkan kerugian yang cukup besar dan berpengaruh terhadap pendapatan peternak. Kerugian akibat adanya infeksi penyakit diantaranya adalah terjadinya penurunan hasil produksi akibat terhambatnya pertumbuhan ternak serta bertambahnya biaya yang harus dikeluarkan untuk pengobatan ternak yang terinfeksi penyakit (Subronto,2007).

Penyakit yang sering diabaikan oleh peternak adalah penyakit yang disebabkan oleh parasit cacing. Dari segi perhitungan ekonomi, penyakit pada sapi yang diakibatkan oleh parasit cacing mengakibatkan kerugian yang sangat tinggi bagi peternak. Infeksi cacing pada saluran pencernaan mengakibatkan gangguan pencernaan sapi dan terjadi kompetisi dalam penyerapan nutrisi makanan sehingga pertumbuhan sapi akan terhambat (BPTP NTB, 2011). Terlebih jika cacing tersebut bersifat zoonosis, selain kerugian ekonomi yang ditimbulkan juga kesehatan mereka terancam (Medicastore, 2011). Berdasarkan uraian tersebut maka perlu dilakukan penelitian mengenai respon pertumbuhan dan mortalitas pedet sapi Bali dari induk yang diberi pakan tambahan dan obat cacing.

\section{METODE PENELITIAN}

Penelitian ini dilaksanakan pada bulan Juni sampai November 2015 di Kecamatan Mowila, Kabupaten Konawe Selatan. Materi penelitian 30 ekor induk sapi Bali yang sedang bunting dengan umur kebuntingan 7 bulan. keturunan dari induk berupa pedet sebanyak 30 ekor diteliti dan diamati pertumbuhannya mulai umur 0 sampai umur 12 minggu. Pakan sapi berupa rumput lapangan sebagai pakan utama dan pakan tambahan (dedak padi) sebanyak $2 \mathrm{~kg}$ per ekor per hari serta obat cacing. Obat cacing diberikan pada umur kebuntingan 7 bulan pada induk sapi.

Alat yang digunakan dalam penelitian ini adalah sebagai berikut :. Timbangan badan digital untuk menimbang pedet sapi Bali. Tongkat ukur yang digunakan untuk mengukur tinggi pundak dan tinggi pinggul pedet sapi. Pita ukur digunakan sebagai alat mengukur panjang badan dan lingkar dada sapi. Alat tulis menulis serta kamera untuk mendokumentasikan penelitian.

Penelitian ini menggunakan 30 ekor induk sapi Bali dengan umur kebuntingan 
7 bulan dibagi dalam 3 kelompok yaitu: Kelompok pertama adalah kelompok kontrol menggunakan 10 ekor sapi Bali dengan umur kebuntingan 7 bulan, dimana pemberian pakan tambahan(dedak) dan obat cacing tidak diberikan. Pada pagi hari sapi dikeluarkan untuk digembalakan dan sore harinya baru dimasukkan ke dalam kandang dan diberikan hijauan, begitu seterusnya. Kelompok kedua adalah kelompok menggunakan 10 ekor sapi Bali dengan umur kebuntingan 7 bulan yang diberi pakan tambahan (dedak) tanpa obat cacing. Pada pagi dan siang hari sapi digembalakan dan pada sore hari diberikan pakan tambahan dan hijauan. Pakan tambahan yang diberikan adalah dedak sebanyak $2 \mathrm{~kg}$ untuk setiap ekor ternak/hari sampai dengan umur pedet 3 bulan. Kelompok ketiga adalah kelompok perlakuan menggunakan 10 sapi Bali dengan umur kebuntingan 7 bulan yang diberi pakan tambahan (dedak) dan obat cacing. Pada pagi dan siang hari sapi digembalakan dan pada sore hari diberikan pakan tambahan dan hijauan. Pakan tambahan yang diberikan adalah dedak sebanyak $2 \mathrm{~kg}$ untuk setiap ekor ternak/ hari sampai dengan umur pedet 3 bulan.

\section{A. Parameter yang diamati}

Data diperoleh berdasarkan penimbangan dan pengamatan setiap minggu pada masing-masing individu. Data yang dikumpulkan yaitu bobot awal, bobot badan, ukuran dimensi tubuh yang meliputi panjang badan, lingkar dada dan tinggi pundak serta mortalitas pedet.

\section{B. Analisis Data}

Data penelitian di analisis dengan menggunakan Rancangan Acak lengkap (RAL) dengan tiga perlakuan yaitu (P2) adalah kelompok sapi Bali bunting yang diberi pakan tambahan dan obat cacing, (P1) adalah adalah kelompok sapi Bali bunting yang diberi pakan tambahan tanpa obat cacing dan (P0) adalah adalah kelompok sapi Bali bunting yang tidak diberi pakan tambahan dan obat cacing. Data yang diperoleh dianalisis menggunakan analisis ragam, selanjutnya untuk mengetahui perbedaan antar perlakuan digunakan uji Beda Nyata Terkecil (BNT) (Casper, 1998).

Model linear Rancangan Acak Lengkap (RAL) yang digunakan yaitu : $\mathrm{Y}_{\mathrm{ij}}=\mu+\alpha_{\mathrm{i}}+\varepsilon_{\mathrm{ij}}$

Dimana :

Tabel 1. Rataan Bobot Badan Pedet Sapi Bali (kg/ekor/)

\begin{tabular}{ccccc}
\hline \multirow{2}{*}{ Umur Lahir } & \multicolumn{3}{c}{ Perlakuan } & \multirow{2}{*}{ Rataan } \\
\cline { 2 - 4 } & P0 & P1 & P2 & \\
\hline 0 minggu & 11,80 & 14,40 & 15,10 & 13,77 \\
2 minggu & 16,95 & 17,15 & 17,25 & 17,12 \\
4 minggu & 26,05 & 26,15 & 26,15 & 26,12 \\
6 minggu & 35,65 & 35,85 & 35,95 & 35,82 \\
8 minggu & 44,95 & 45,50 & 45,85 & 45,43 \\
10 minggu & 51,80 & 52,30 & 52,40 & 52,17 \\
12 minggu & 56,95 & 57,45 & 57,90 & 57,43 \\
\hline
\end{tabular}

Keterangan : $\mathrm{P} 0=$ Tanpa perlakuan

$\mathrm{P} 1=$ Konsentrat

$\mathrm{P} 2=$ Konsentrat + obat cacing 
$\mathrm{Y}_{\mathrm{ij}}=$ Pengamatan pada perlakuan ke-i dan ulangan ke-j

$\mu \quad=$ Rataan umum

$\alpha_{\mathrm{i}}=$ Pengaruh perlakuan taraf ke-i

$\varepsilon_{\mathrm{ij}}=$ Pengaruh galat dari perlakuan

\section{HASIL DAN PEMBAHASAN}

\section{A. Bobot Badan}

Rataan bobot badan pada pedet sapi Bali dari induk yang diberi pakan tambahan dan obat cacing selama penelitian disajikan pada Tabel 1 .

Berdasarkan Tabel 1 rataan bobot badan pedet sapi Bali dari induk yang diberi pakan tambahan dan obat cacing pada umur 0-12 minggu pada masingmasing perlakuan tidak berpengaruh ini disebabkan karena pedet berada pada tahap masa pertumbuhan yang sama. Menurut Imran et al. (2012) bahwa pada pertumbuhan sapi dengan tingkat konsumsi pakan yang relatif sama pada taraf protein berbeda yang diberikan, memiliki pertumbuhan yang dihasilkan relatif sama. Secara visual rataan bobot badan pedet sapi Bali dari induk yang diberi pakan tambahan dan obat Cacing dapat dilihat pada Gambar 1.

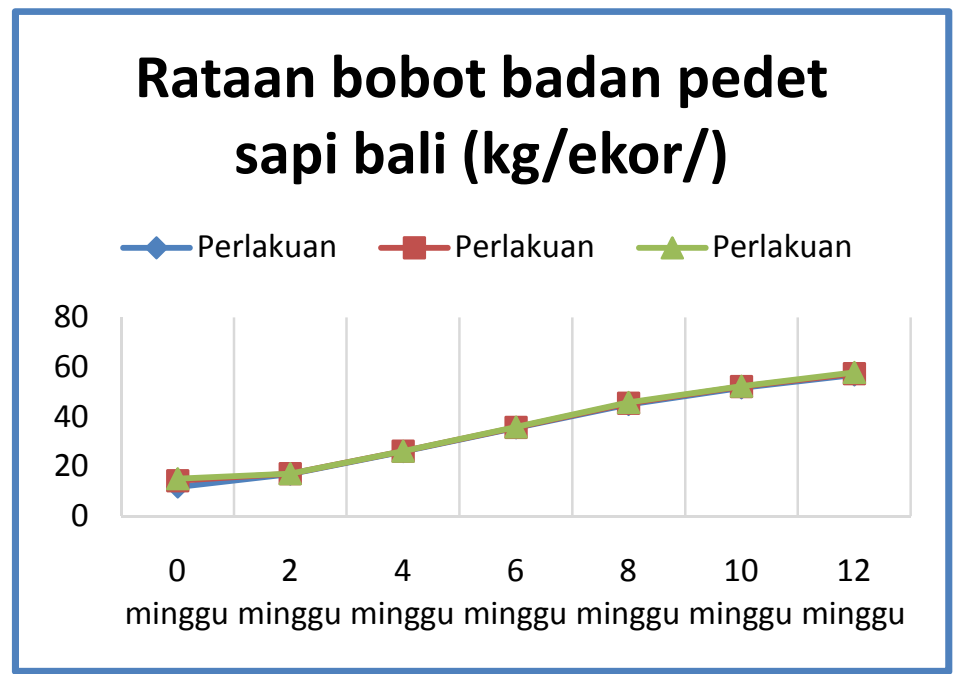

Gambar 1. Grafik Bobot Badan Selama Penelitian

Tabel 2. Rataan Lingkar Dada Pedet Sapi Bali (cm/ekor)

\begin{tabular}{ccccc}
\hline \multirow{2}{*}{ Umur Lahir } & \multicolumn{3}{c}{ Perlakuan } & \multirow{2}{*}{ Rataan } \\
\cline { 2 - 4 } & P0 & P1 & P2 & \\
\hline 0 minggu & 67,30 & 70,00 & 71,50 & 69,60 \\
2 minggu & 67,50 & 70,15 & 71,75 & 69,80 \\
4 minggu & 69,45 & 72,30 & 74,05 & 71,93 \\
6 minggu & 71,60 & 74,75 & 76,65 & 74,33 \\
8 minggu & 75,15 & 78,20 & 79,85 & 77,73 \\
10 minggu & 80,00 & 81,95 & 84,05 & 82,00 \\
12 minggu & 83,25 & 84,40 & 86,25 & 84,63 \\
\hline
\end{tabular}


Berdasarkan Gambar 1 terlihat bahwa perlakuan P2 memiliki bobot badan yang cenderung lebih tinggi dibanding dengan perlakuan P0 dan P1 meskipun secara statistik tidak berbeda nyata $(\mathrm{P}>0,05)$.

Hal ini disebabkan ternak memiliki bobot lahir yang lebih besar dibanding dengan ternak lain. Sesuai dengan hasil penelitian Subiharta et al. (2000) menunjukkan bahwa dengan "flushing" melalui pemberian pakan konsentrat pada induk sapi bunting berumur 8 bulan sampai pedet berumur 2-3 bulan, bobot lahir pedet dapat meningkat.

\section{B. Lingkar Dada}

Rataan lingkar dada pedet sapi Bali dari induk yang diberi pakan tambahan dan obat cacing selama penelitian dapat dilihat pada Tabel 2 .

Berdasarkan Tabel 2 terlihat bahwa rataan lingkar dada pedet sapi Bali dari induk yang diberi pakan tambahan dan obat cacing pada masing-masing perlakuan dari minggu ke-2 sampai minggu ke-12 mengalami peningkatan pada setiap bulannya. Berdasarkan Tabel diatas perlakuan yang tertinggi didapat pada P2, P1 dan menyusul P0. Lingkar dada pada pedet sapi Bali yang diteliti tidak jauh berbeda dengan penelitian Sulistyowati et al. (2000) bahwa pada pertumbuhan pedet sapi Bali dan sapi Madura sejak lahir hingga empat minggu mempunyai lingkar dada $(58,3-73,0 \mathrm{~cm}$ vs 60,0-66,7 cm). Pemberian pakan tambahan dan obat cacing pada induk pedet cenderung lebih baik dan menghasilkan lingkar dada yang lebih besar dibanding tanpa perlakuan sebab pemberian konsentrat dapat mencukupi nilai nutrisi untuk kebutuhan hidup ternak, memberikan pengaruh positif terhadap pertumbuhan. Djagra (2009) menyatakan pertumbuhan dipengaruhi oleh zat-zat makanan, genetik, jenis kelamin dan hormon. Susilo (2013) pemberian obat cacing secara umum dapat memperbaiki body condition score (BCS), serta peningkatan status reproduksi dan status kesehatan hewan. Rataan pertambahan lingkar dada pedet sapi Bali dari induk yang diberi pakan tambahan dan obat cacing dapat dilihat pada Gambar 2.

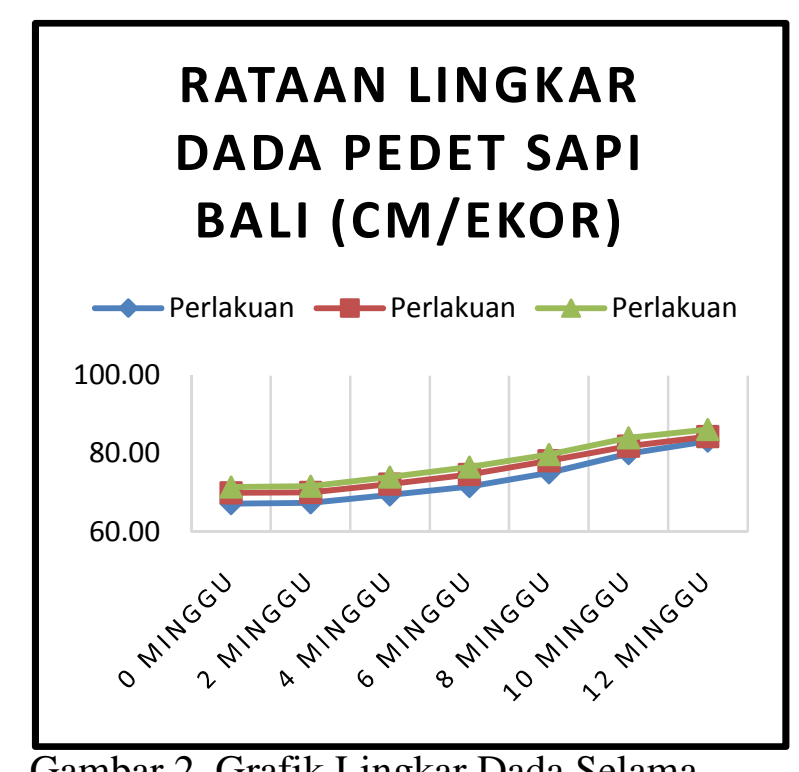

Gambar 2. Grafik Lingkar Dada Selama Penelitian

Pada Gambar 2 menunjukkan bahwa pertambahan lingkar dada pedet sapi Bali pada tiap perlakuan relatif homogen. Waktu pertumbuhan sapi mulai memasuki masa dara atau pubertas terjadi perubahan ukuran lingkar dada. Rata-rata perkembangan lingkar dada mencapai pertumbuhan yang pesat, hal ini disebabkan karena bagian tubuh yang berfungsi lebih awal atau lebih dini akan berkembang lebih dulu. Bagian dari tubuh hewan tumbuh dengan cara teratur, namun tidak tumbuh dengan suatu kesatuan karena berbagai jaringan tumbuh dengan laju yang berbeda dari lahir sampai dewasa. Sedangkan dimensi lingkar, yang 
Tabel 3. Rataan Tinggi Gumba Pada Pedet Sapi Bali (cm/ekor)

\begin{tabular}{ccccc}
\hline \multirow{2}{*}{ Umur Lahir } & \multicolumn{3}{c}{ Perlakuan } & \multirow{2}{*}{ Rataan } \\
\cline { 2 - 4 } & P0 & P1 & P2 & \\
\hline 0 minggu & 59,40 & 59,90 & 60,70 & 60,00 \\
2 minggu & 60,00 & 60,50 & 61,25 & 60,58 \\
4 minggu & 62,70 & 63,00 & 63,50 & 63,07 \\
6 minggu & 65,70 & 66,10 & 66,35 & 66,05 \\
8 minggu & 68,20 & 68,90 & 69,25 & 68,78 \\
10 minggu & 70,55 & 71,05 & 71,65 & 71,08 \\
12 minggu & 72,60 & 72,85 & 73,35 & 72,93 \\
\hline
\end{tabular}

paling dulu tumbuh adalah lingkar dada kemudian lingkar abdomen, lingkar leher bagian bawah dan yang terakhir tumbuh adalah lingkar leher bagian atas.

\section{Tinggi Gumba}

Rataan pertambahan tinggi gumba pedet sapi Bali dari induk yang diberi pakan tambahan dan obat cacing selama penelitian dapat dilihat pada Tabel 3.

Rataan tinggi gumba pedet sapi Bali dari induk yang diberi pakan tambahan dan obat cacing pada minggu ke-0 sampai minggu ke-12 selama penelitian tidak menunjukkan pengaruh yang nyata $(\mathrm{P}>0,05)$. Tinggi gumba pada pedet sapi bali yang diteliti tidak jauh berbeda dengan penelitian Sulistyowati et al., (2000) bahwa pada pertumbuhan pedet sapi Bali dan sapi Madura sejak lahir hingga empat minggu mempunyai tinggi gumba $(57,7-68,1 \mathrm{~cm}$ vs $61,6-$ $66,3 \mathrm{~cm})$.

Pada Tabel 3 tinggi gumba menunjukkan tiap bulannya bertambah hal ini diduga karena pertumbuhan otot dan tulang terutama terakumulasi pada tulang kaki sehingga mempengaruhi tinggi gumba. Tinggi gumba pedet sapi jantan dan betina pada umur 0-6 bulan mengalami pertumbuhan yang lebih cepat dari pada pinggulnya. Perbedaan tuntutan fisiologis dan fungsional yang berbeda berakibat pula perbedaan urutan pertumbuhan (Sampurna et al., 2013). Rataan pertambahan tinggi gumba pedet sapi Bali dari induk yang diberi pakan tambahan dan obat cacing dapat dilihat pada Gambar3.

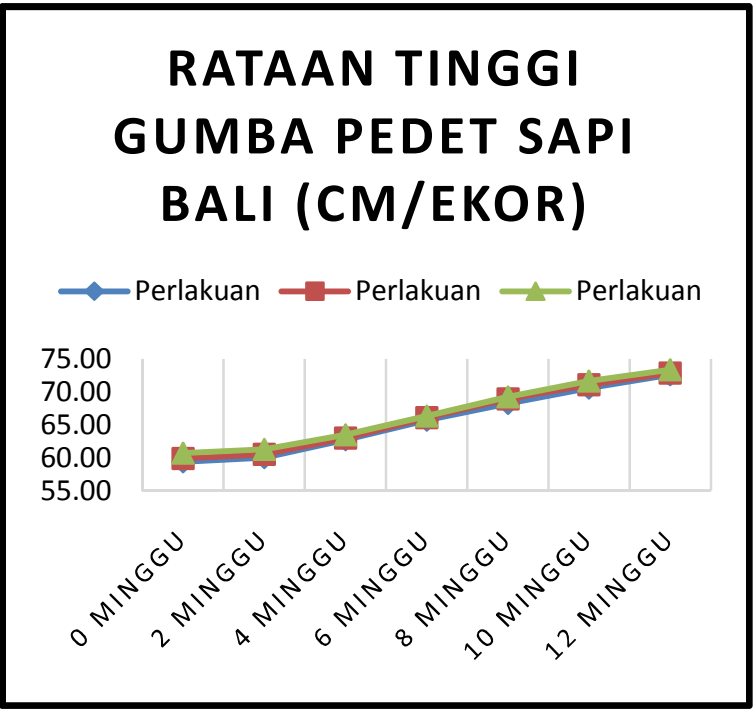

Gambar 3. Grafik Tinggi Gumba Selama Penelitian

Pada Gambar 3 rata-rata tinggi gumba P2 lebih tinggi dari pada P1 dan P0 hal ini disebabkan karena manajemen pemeliharaan pedet yang kurang baik sebab dipelihara secara non-intensif. Perbedaan pertumbuhan pedet sapi bali juga disebabkan karena jenis kelamin yang berbeda sebab pada sapi jantan kaki bagian depannya lebih aktif bergerak pada 
Tabel 4. Rataan Panjang Badan Pada Pedet Sapi Bali (cm/ekor)

\begin{tabular}{ccccc}
\hline \multirow{2}{*}{ Umur Lahir } & \multicolumn{3}{c}{ Perlakuan } & \multirow{2}{*}{ Rataan } \\
\cline { 2 - 4 } & P0 & P1 & P2 & \\
\hline 0 minggu & 54,50 & 54,60 & 54,80 & 54,63 \\
2 minggu & 54,95 & 55,10 & 55,30 & 55,12 \\
4 minggu & 56,50 & 57,10 & 57,15 & 56,92 \\
6 minggu & 58,40 & 58,75 & 59,40 & 58,85 \\
8 minggu & 60,60 & 60,95 & 61,90 & 61,15 \\
10 minggu & 63,20 & 63,75 & 64,40 & 63,78 \\
12 minggu & 65,54 & 66,20 & 66,70 & 66,15 \\
\hline
\end{tabular}

saat pedet menyusu pada induknya. Perbedaan bentuk fisiologis dan fungsional dapat mempengaruhi urutan pertumbuhannya (Sampurna et al, 2013).

\section{Panjang Badan}

Rataan panjang badan pedet sapi Bali dari induk yang diberi pakan tambahan dan obat cacing selama penelitian dapat dilihat pada Tabel 4. Rataan panjang badan pada pedet sapi Bali dari induk yang diberi pakan tambahan dan obat cacing pada minggu ke-2 sampai minggu ke-12 mengalami peningkatan pada setiap bulannya. Rataan pertambahan panjang badan pedet sapi Bali dari induk yang diberi pakan tambahan dan obat cacing dapat dilihat pada Gambar 4.

\section{RATAAN PANJANG BADAN PEDET SAPI BALI (CM/EKOR)}

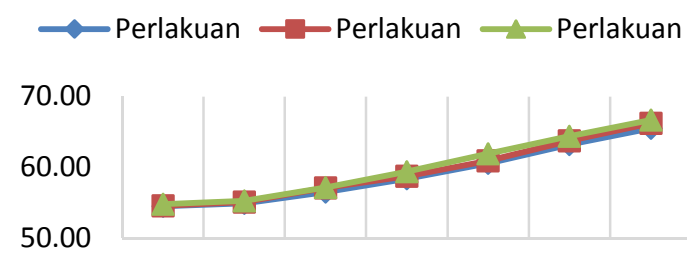

Gambar 4. Grafik Panjang Badan Selama Penelitian

Berdasarkan pada Gambar 4 menunjukkan grafik pertambahan panjang badan P2 memiliki pertumbuhan yang lebih besar dari pada P1 dan P0. Panjang badan memiliki hubungan korelasi dengan bobot badan jika bobot sapi pedet tinggi maka panjang badannya juga cenderung lebih besar. Menurut Sulistyowati et al. (2009) bobot badan pedet sapi umur satu bulan dipengaruhi cukup kuat oleh lingkar dada dan panjang badan. Selama masa kebuntingan terutama pada tiga bulan terakhir dan selama masa laktasi, induk ternak memerlukan pakan dengan kualitas dan kuantitas yang memadai dalam 
jumlah dan mutu agar pertumbuhan janin dan pedet selama prasapih tetap normal (Roy, 1959). Jumlah pakan yang cukup, pedet akan mempunyai bobot badan normal dan tumbuh sehat. Sapi induk yang sedang menyusui, terutama yang digunakan sebagai hewan kerja untuk mengolah tanah, memerlukan energi dan fosfor dalam jumlah cukup agar produktivitasnya tidak terganggu (Lebdosukoyoet al., 1979).

\section{E. Mortalitas.}

Berdasarkan hasil pengamatan terhadap mortalitas pedet sapi Bali didapatkan persentase mortalitas $0 \%$ hal ini dikarenakan pada saat pengambilan data dilakukan pada musim kemarau. Menurut Sayuti (2007) mengatakan bahwa musim kemarau sangat berhubungan dengan tingkat kejadian cacingan yang cukup rendah karena pada musim kemarau dapat mengganggu perjalanan siklus hidup cacing, kondisi tanah yang kering dan atmosfer yang cukup panas menyebabkan feses cepat mengering sehingga telur cacing menjadi rusak dan mati. Berbeda dengan yang terjadi pada musim hujan atau kondisi lingkungan lembab dan basah karena manajemen pemeliharaan yang kurang baik. Kondisi tersebut menjadi media yang cocok untuk perkembangan telur cacing menjadi bentuk yang siap masuk ke dalam tubuh sapi sehingga terjadi tingkat cacingan yang cukup tinggi pada musim hujan. Menurut Mohammed (2008) bahwa keadaan alam Indonesia dengan curah hujan dan kelembaban yang tinggi, dan ditunjang pula oleh sifatnya yang hemaprodit akan mempercepat perkembangbiakan cacing. cacing mutlak membutuhkan air dalam keadaan tergenang untuk melangsungkan daur perkembangannya (Suweta, 1985).

\section{KESIMPULAN}

Berdasarkan hasil dan pembahasan dapat disimpulkan bahwa pemberian pakan tambahan dan obat cacing pada induk dengan umur kebuntingan 7 bulan sampai pedet umur 3 bulan tidak berpengaruh nyata $(\mathrm{P}>0.05)$ terhadap pertambahan bobot badan, lingkar dada, tinggi gumba dan panjang badan pedet. Namun demikian perlakuan pemberian obat cacing dan pakan tambahan tersebut cenderung memberikan performans pedet sapi Bali yang lebih baik.

\section{DAFTAR PUSTAKA}

Deptan. 2001. Beberapa Penyakit Pada Ternak Ruminansia "Pencegahan dan Pengobatannya". Departemen Pertanian. Badan Penelitian dan Pengembangan. Balai Pengkajian Teknologi Pertanian. NTB.

Djagra, I.B. 2009. Diktat Ilmu Tilik Sapi Potong. Fakultas Peternakan Universitas Udayana, Denpasar.

Feati. 2011. Teknologi Penggemukan Sapi Bali. -BPTP NTB it-2.pdf.

Imran, S. P. S., Budhi, N. N. dan Dahlanuddin. 2012. pertumbuhan pedet sapi bali lepas sapih yang di beri rumput lapang an dan disuplementasi daun turi. Jurnal Ilmu Ternak dan Tanaman, Vol (2) $2: 69-80$.

Medicastore. 2011. Toxocariasis. Infeksi dan Penyakit Menular. http://medicastore.com/penyakit/2 20/Toksokariasis.html (05-022016)

Mohammed, N. 2008. Fasciola hepatica. http://www.nenadmohamed.com.h tm.(05-02-2016). 
Sampurna I.P, Saka I.K, Oka I.G.L, Sentana P. 2013. Biplot Simulation of Exponential Function to Determine Body Dimension's Growth Rate of Bali Calf. Canadian Journal on Computing in Mathematics, Natural Scienses, Engineering and Medicine, 4 (1) : $87-92$.

Sayuti, Linda. (2007). Kejadian Infeksi Cacing Hati (Fasciola sp.) pada Sapi bali di Kabupaten Karangasem. Bogor: Institut Pertanian Bogor

Sulistyowati, E., S.A. Abutani, R. Saefuddin, E. Soetrisno. 2009. Produktivitas Pedet Sapi Bali dan Pedet Sapi Madura Ditinjau dari Ukuran Tubuh Sejak Lahir sampai Umur Empat Minggu. Prosiding Seminar Nasional Sapi dan Kerbau - Fakultas Peternakan Universitas Andalas. Padang.

Susilo, J. 2013. Pengaruh Pemberian Vitamin B Kompleks dan Obat Cacing TerhadapPeningkatan Bobot Badan Sapi Potong serta Pendapatan Petani di Desa Margorejo Kabupaten Pati. Medik
Veteriner Balai Veteriner Lampung

Subiharta, U. Nuschati, B. Utomo, D. Pramono, S. Prawirodigdo, T. Prasetyo, A. Musofie, Ernawati, J. Purmiyanto, dan Suharno, 2000. Laporan Hasil Kegiatan Pengkajian Sistem Usaha Tani Pertanian Sapi Potong di Daerah Lahan Kering. Balai Pengkajian Teknologi Pertanian Ungaran. Semarang.

Subronto. 2008. Ilmu Penyakit Ternak. Yogyakarta: Gadjah Mada University Press. 58-61

Suweta, I.G.P. 1985. Penyuluhan Penggulangan Penyakit Parasiterpada Ternak di Kabupaten Gianyar. Laporan Penelitian. PusatPengabdian Pada Masyarakat. Universitas Udayana, Denpasar.

Wirdahayati, R.D. dan A. Bammualim. 2003. Produktivitas Ternak Sapi di Nusa Tenggra Timur, Indonesia (Cattle Productivity in Nusa Tenggara Timur, Indonesia). Laporan Penelitian. Sub Balai Penelitian Ternak, Lili, Kupang. 